\title{
An Evaluation of the Role of Britain in The Formation of Iranian Constitutionalism
}

\author{
Nazanin Esmaeelpour
}

\begin{abstract}
In this research, the scholar has attempted to evaluate the role of Britain in the formation of Iranian constitutionalism, 1906.

The research question was as follows:

- How did Britain influence over formation of Iranian constitutionalism?

The research hypothesis was as follows:

- The government of Britain, regarding its long-lasting goals and programs has had an effective role in the formation of Iranian constitutionalism.

For confirmation of this hypothesis, the scholar has studied historical background and examined its social, economical, political, and cultural context.

Furthermore, the reciprocal relationships and effects between all of influential and notable factures, such as foreign powers, international cataclysmic changes, intellectual constitutionalists, and religious figures; and their effects in the formation of public opinions has studied.

Then, the role of Britain was explained with impressionability of the intellectuals and their influence on religious leaders and specially with the description of people's seeking sanctuary in the British embassy.

As a result, the scholar has concluded indirect role of Britain as an effective power on constitutionalists, is more important than its direct role; therefore, the role of Britain in the formation of Iranian constitutionalism is undeniable and the hypothesis of this research has confirmed.
\end{abstract}

Keywords: Britain, Iranian constitutionalism, parliament, intellectual constitutionalists, religious figures. 